\title{
Evaluation of Soil Fertility Using Multivariate Analysis and GIS in Moghra Oasis, Egypt
}

\author{
A. M. Ali and S. M. Ibrahim \\ Department of Soil Fertility and Microbiology, Desert \\ Research Centre, El-Mataryia, Cairo 11753, Egypt
}

\begin{abstract}
T NDERSTANDING spatial variability of soil properties is important for refining soil fertility management that leads to high crop yields at reduced crop production costs and helps protect the environment. This study was undertaken in order to create soil management zones in the Moghra Oasis, North-East Qattara Depression, Egypt on the basis of variation in several soil parameters. Representative soil samples were collected at two depths $(0-30 \mathrm{~cm}$ and $30-60 \mathrm{~cm})$ from the study area. Substantial variation was observed in elevation, soil salinity, $\mathrm{pH}$, available $\mathrm{P}, \mathrm{K}, \mathrm{Fe}, \mathrm{Mn}$, $\mathrm{Zn}, \mathrm{Cu}$ and $\mathrm{B}$ of the soils. Spatial variability pertaining to soil parameters was studied using kriging technique in GIS. Principal component analysis was performed in order to detect patterns, groupings, similarities or differences of soil parameters. The analysis showed that soil salinity, elevation and $\mathrm{pH}$ are the parameters that function as indicators of the multiple soil parameters in the study area. Accordingly, overlay process was performed between these parameters and five distinct zones were created. This can be considered a system for grouping soils according to the main fertility-related soil constraints and yield-limiting factors for specific agronomic management. Therefore, these zones should be helpful to the decision makers to commence exploiting the areas with fewer constraints as well as optimizing the agricultural inputs.
\end{abstract}

Soil fertility is not only the basis of land productivity, but it also reveals soil quality (Wu et al., 2010 and Li and Zhang, 2011). It is not an easy task to define soil fertility of a given region because there may exist great difference in the temporal and spatial variability in soil fertility (Zheng et al., 2004). Some subjective factors also get mixed in it when evaluating soil fertility leading to objective authenticity of the evaluation and results unguaranteed (Li and Zhang, 2011). Accordingly, many indicators can reflect soil fertility, such as physical, chemical and biological indicators and not only soil nutrients level (Filip, 2002 and Huang and Yang, 2009). The comprehensive evaluation of soil fertility increasingly depends on mathematical methods at present (Garey and Roopa, 2005). The Moghra Oasis, North-East Qattara Depression is one of the targeted areas for agricultural development as a megaproject in Egypt. There are several technical soil classification systems in use for several specific purposes such as land capability and suitability. However, a system for grouping soils according to fertility-related soil constrains as a complementary for agronomic management decisions is needed in this area. 
Applying fertilizers and other agricultural inputs uniformly as a general recommendation over large areas is the main adopted management strategy in Egypt and majority of developing countries. General recommendations are increasingly proving as inefficient because these result in the over-application of inputs in low-producing areas and sub-optimal application in areas with highproduction potential. Several studies have documented that soil properties vary across farm fields, causing spatial variability in crop yields (Gaston et al., 2001). For example, numerous studies have indicated economic and environmental justification for spatially variable $\mathrm{N}$ applications in many agricultural landscapes (Koch et al., 2004; Scharf et al., 2005; Lambert et al., 2006). Therefore, an appropriate understanding of spatial variability in soil properties is essential at landscape scale for fertility management.

Introducing Geographic Information Systems (GIS) technology has facilitated describing the spatial variability of fields. GIS is a powerful set of tools for collecting, storing, retrieving, transforming and displaying spatial data (Burrough and McDonnell, 1998). It allows fields to be mapped accurately and also allow complex spatial relationships between soil data layers (Ali et al., 2008). Therefore, GIS can be used in producing soil maps that help understand the status of soil fertility spatially and temporally. Therefore, it is helpful in formulating site-specific management.

The concept of 'management zone' was evolved in response to large variability in soil with the main purpose of optimizing the agricultural inputs. Site-specific management zones are defined as homogeneous sub-regions of a field that have similar yield limiting factors (Doerge, 1999 and Khosla \& Shaver, 2001). Site-specific management is aimed at managing soil spatial variability by applying inputs in accordance with the site-specific requirements of a specific soil and crop (Fraisse et al., 2001). Conceptually, by using a management zone delineation technique, an agricultural field could be classified into management zones that reflect the overall variation in soil properties. There are considerable attempts to delineate management zones. Topography has been suggested as a logical basis to define homogenous zones in agricultural fields (Franzen et al., 2002). Several studies have described the relationship between field topography and soil $\mathrm{N}$ content (Bruulsema et al. 1996 and Cassel et al., 1996) as well as topography and yield variation (Verity and Anderson 1990). Kravenchenko and Bullock (2000) found that topography together with other data such as organic matter, cation exchange capacity, $\mathrm{P}$ and $\mathrm{K}$ accounted for $40 \%$ of the variation in grain yield. Aerial photographs, crop canopy images, and yield maps have also been suggested as approaches to delineate management zones (Schepers et al., 2000). Remote sensing technology has also been used for identify management zones as a low in cost technique (Mulla and Schepers, 1997).

Multivariate statistical techniques are important for viewing and analysing some matrices of complex data (Da-Silva et al., 2006). Principal component analysis (PCA), a type of multivariate analysis, is a powerful tool for pattern Egypt. J. Soil Sci. 56, No. 4 (2016) 
recognition, classification, modelling and other aspects of data evaluation (Csomos et al., 2002). It allows deducing how certain variables that characterize objects determine their association. It estimates the correlation structure of the variables by finding hypothetical new variables (principal components) that account for as much as possible of the variance in a multidimensional data set. These new variables are linear combinations of the original variables (Hammer et al., 2001). They then reflect how much each variable contributes to the meaningful variation in the data and to interpret variables relationship.

The objectives of undertaking the present study were: i) to identify spatial variability of soil parameters using GIS technique, ii) to identify the main parameters that function as direct and/or indirect indicators of multiple soil parameters using PCA, and iii) to delineate soil management zones that reflect the overall variation in soils of Moghra Oasis.

\section{Materials and Methods}

\section{Site description}

The study area is located at Moghra Oasis, North-East Qattara Depression, Western desert of Egypt (Map 1). It lies between 30 07' 49" $\mathrm{N}$ to $30^{\circ} 22^{\prime} 13^{\prime \prime} \mathrm{N}$ latitude and $28^{\circ} 37^{\prime} 21^{\prime \prime} \mathrm{E}$ to $29^{\circ} 11^{\prime} 12^{\prime \prime} \mathrm{E}$ longitude. It is spread over an area of about 143000 ha. This area is one of the targeted areas in Egypt for agricultural development as a megaproject. Moghra Lake is located in the middle of the study area. The lake occupies around 400 ha area and contains brackish water. There are separated jojoba, olive and pomegranate orchards irrigated from wells. There is a plan to drill several wells in this area as a source of irrigation water by the Egyptian government. The climate is arid with annual rainfall between 25 to 50 $\mathrm{mm}$ year ${ }^{-1}$. The mean daily temperature averages between $36.2^{\circ}$ and $6.5^{\circ} \mathrm{C}$ during summer and winter months, respectively. The prevailing wind comes from the North varying between north-west and north-east directions.

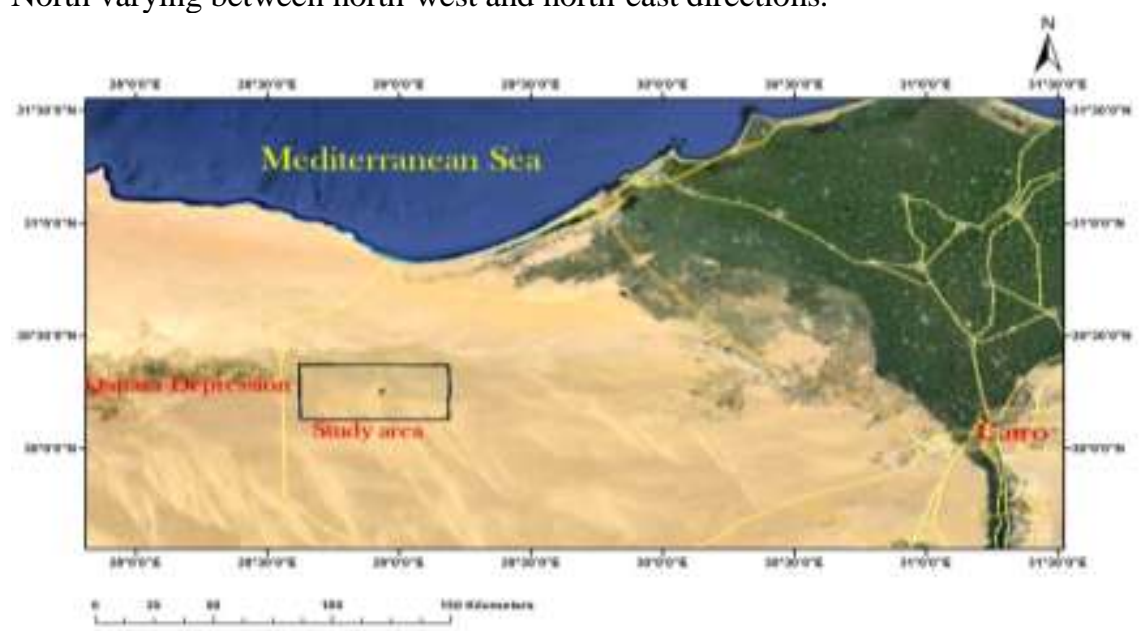

Map 1. Location of the study area

Egypt. J. Soil Sci. 56, No. 4 (2016) 
Samples collection and Laboratory work

The fieldwork was carried out during July, 2015. The soil samples were collected from 42 locations at two depths $(0-30 \mathrm{~cm}$ and $30-60 \mathrm{~cm})($ Fig. 1). The subsoil at the north-western part is rocky (about 13000 ha). Therefore, the topsoil samples have been replicated at this part. The locations of each sample have been recorded by handheld GPS receiver for further spatial analysis.

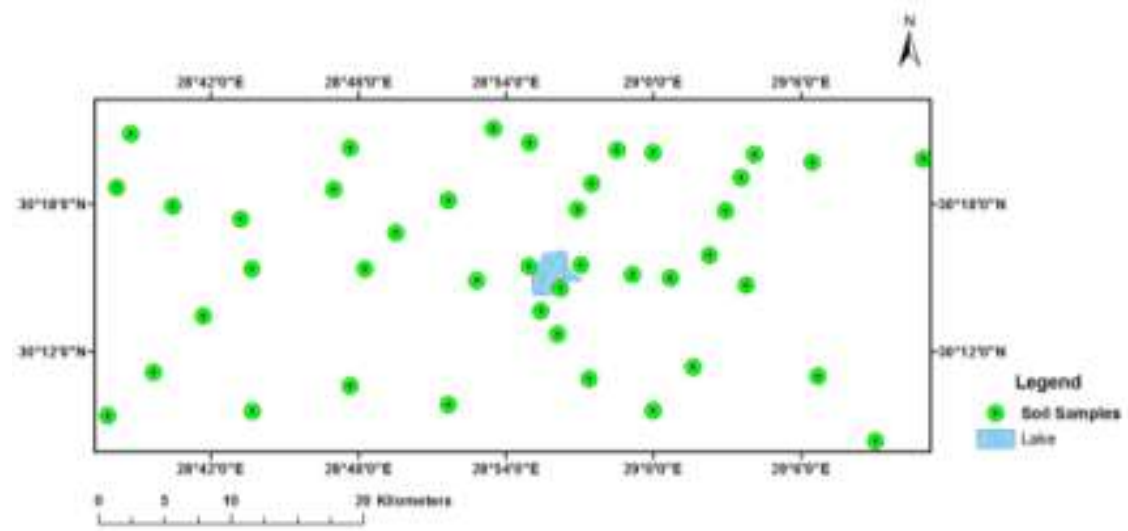

Fig. 1. Locations of soil samples

The collected soil samples were air dried and gently grounded, then sieved through a $2 \mathrm{~mm}$ sieve. The texture in the study area is sandy, ranging from fine sand to medium sand (data not shown). Therefore, soil texture has been excluded from this study since there is no heterogeneity in its values. Values of $\mathrm{pH}$ and electrical conductivity (EC) were measured in 1:2.5 soil-water suspension and supernatant, respectively as described by Page et al. (1982). Soil organic matter was determined using the procedure of Walkely and Black as outlined by Page et al. (1982). Total calcium carbonate content was measured using calcimeter according to Page et al. (1982). Available $\mathrm{N}$ was extracted by $2 M \mathrm{KCl}$ solution, according to Dahnke and Johnson (1990) and then determined by micro-Kjeldahl method according to Page et al. (1982). Available $\mathrm{P}, \mathrm{K}, \mathrm{Fe}, \mathrm{Mn}, \mathrm{Zn}, \mathrm{Cu}$ and $\mathrm{B}$ were extracted by $1 M \mathrm{NH}_{4} \mathrm{HCO}_{3}$ in $0.005 M$ DTPA adjusted to a pH of 7.6 (Soltanpour, 1991). Phosphorus was estimated colorimetrically using ascorbic acid and ammonium molybdate using spectrophotometer as described by (Page et al. 1982). Potassium was measured using flamphotometer according to Page et al. (1982). Iron, $\mathrm{Mn}, \mathrm{Zn}, \mathrm{Cu}$ and $\mathrm{B}$ were determined using inductively coupled plasma-atomic emission spectroscopy as described by Varma (1991).

\section{GIS work and statistical analysis}

ArcGIS 10.0 software was used to interpolate the results from the point data to the entire area. Kriging interpolation technique was used for the estimation of the spatial distribution of soil data. Descriptive statistics and PCA of soil data were performed using Statistical Product and Service Solutions (SPSS 18.0).

Egypt. J. Soil Sci. 56, No. 4 (2016) 


\section{Results and Discussion}

\section{Descriptive statistics and spatial analysis of soil data}

Table 1 summarizes the descriptive statistics of soil data for the whole study area. Values of $\mathrm{pH}$ were converted to the $\mathrm{H}^{+}$ion concentration for statistical analysis, and transformed back to the negative $\log$ of the $\mathrm{H}^{+}$ion for reporting. Standard criteria as depicted in Wilding et al. (1994) were used to determine the magnitude of variabilities. All soil data showed high variability; except for $\mathrm{CaCO}_{3}$ and available $\mathrm{N}$, which were having low values.

The spatial data layers collected for the study area included elevation, soil salinity, $\mathrm{pH}, \mathrm{CaCO}_{3}$, available $\mathrm{P}$, available $\mathrm{K}$, available $\mathrm{Fe}$, available $\mathrm{Mn}$, available $\mathrm{Zn}$, available $\mathrm{Cu}$ and available $\mathrm{B}$. Organic matter and available $\mathrm{N}$ were excluded because these values were very low to show distinct variation.

Figures 2 to 20 show the spatial distribution of soil parameters in the study area. There was a substantial variability in topography, with elevation varying from $-33 \mathrm{~m}$ to $130 \mathrm{~m}$ creating a geographically rough area. The topsoil and subsoil EC ranged from 0.208 to $41 \mathrm{dS} \mathrm{m}^{-1}$. This corresponds to a wide range of soil salinity from very low to very high. The topsoil and subsoil $\mathrm{pH}$ ranged from neutral (6.77) to strongly alkaline (9.89). Calcium carbonate ranged from 3.70 to $6.17 \%$ in topsoil and subsoil. These values do not put these soils within the scope of calcareous soils. Available $\mathrm{P}$ ranged from low $\left(0.72 \mathrm{mg} \mathrm{kg}^{-1}\right)$ to adequate $\left(7.21 \mathrm{mg} \mathrm{kg}^{-1}\right)$ in topsoil and subsoil. Available $\mathrm{K}$ ranged from low $\left(24.51 \mathrm{mg} \mathrm{kg}^{-1}\right)$ to adequate $\left(367.69 \mathrm{mg} \mathrm{kg}^{-1}\right)$ in topsoil and subsoil. Available Fe ranged from low $\left(1.78 \mathrm{mg} \mathrm{kg}^{-1}\right)$ to high $\left(26.07 \mathrm{mg} \mathrm{kg}^{-1}\right)$ in topsoil and subsoil. Available Mn ranged from low $\left(0.42 \mathrm{mg} \mathrm{kg}^{-1}\right)$ to high $\left(13.54 \mathrm{mg} \mathrm{kg}^{-1}\right)$ in topsoil and subsoil. Available $\mathrm{Zn}$ ranged from low $\left(0.16 \mathrm{mg} \mathrm{kg}^{-1}\right)$ to high $\left(6.68 \mathrm{mg} \mathrm{kg}^{-1}\right)$ in topsoil and subsoil. Available $\mathrm{Cu}$ ranged from low $(0.006 \mathrm{mg}$ $\left.\mathrm{kg}^{-1}\right)$ to high $\left(3.308 \mathrm{mg} \mathrm{kg}^{-1}\right)$ in topsoil and subsoil. Available B ranged from low $\left(0.055 \mathrm{mg} \mathrm{kg}^{-1}\right)$ to high $\left(18.76 \mathrm{mg} \mathrm{kg}^{-1}\right)$ in topsoil and subsoil.

A closer look to the figures shows that soil salinity is high at low elevations. It is noticeable also that the other soil data distributions follow a distinct trend due these variations as well. In arid and semiarid regions, the water in depressions evaporates and the salts in the water accumulate. Underground water also moves upward and evaporates. The salts are deposited near or on the soil surface to form saline, alkaline or saline-alkaline soils. This phenomenon is well explained in FAO (1988).

The basic concept behind site-specific management is that an area should be evaluated and managed according to spatial variability of potential soil properties. Variability can give valuable insight into the dynamic nature of soil properties within boundary of an area. As reported by Inman et al. (2005), fields that have a high degree of spatial variability in soil prosperities could be better managed using site-specific management zones. 
TABLE 1. Descriptive statistics of topsoil and subsoil properties of Moghra Oasis area

\begin{tabular}{|c|c|c|c|c|c|c|}
\hline & Depth (cm) & Minimum & Maximum & Mean & SD* & $\mathrm{CV}(\%)^{*}$ \\
\hline Elevation & -- & -33.00 & 130.00 & 18.96 & 38.33 & 202.14 \\
\hline \multirow{2}{*}{$\mathrm{EC}, \mathrm{dS} \mathrm{m}^{-1}$} & $0-30$ & 0.28 & 30.60 & 5.38 & 9.06 & 168.21 \\
\hline & $30-60$ & 0.21 & 41.00 & 7.27 & 12.97 & 178.50 \\
\hline \multirow{2}{*}{ Soil reaction as $\left[\mathrm{H}^{+}\right], M$} & $0-30$ & $\begin{array}{c}2.089 \mathrm{E}-10 \\
(6.85)^{* * * *}\end{array}$ & $\begin{array}{c}1.413 \mathrm{E}-7 \\
(9.68)\end{array}$ & $\begin{array}{c}8.023 \mathrm{E}-9 \\
(8.59)\end{array}$ & $2.232 \mathrm{E}-8$ & 278.20 \\
\hline & $30-60$ & $\begin{array}{c}1.288 \mathrm{E}-10 \\
(6.77)\end{array}$ & $\begin{array}{c}1.698 \mathrm{E}-7 \\
(9.89) \\
\end{array}$ & $\begin{array}{c}1.114 \mathrm{E}-8 \\
(8.61)\end{array}$ & $2.928 \mathrm{E}-8$ & 262.93 \\
\hline \multirow{2}{*}{$\mathrm{CaCO}_{3}, \%$} & $0-30$ & 3.76 & 6.17 & 5.08 & 0.54 & 10.57 \\
\hline & $30-60$ & 3.70 & 5.56 & 4.76 & 0.48 & 10.08 \\
\hline \multirow{2}{*}{$\mathrm{OM}, \%$} & $0-30$ & 0.02 & 0.10 & 0.05 & 0.02 & 35.54 \\
\hline & $30-60$ & 0.01 & 0.08 & 0.04 & 0.02 & 41.80 \\
\hline \multirow{2}{*}{ Available $\mathrm{N}, \mathrm{mg} \mathrm{kg}^{-1}$} & $0-30$ & 16.90 & 25.10 & 19.17 & 2.59 & 13.50 \\
\hline & $30-60$ & 15.00 & 22.60 & 17.11 & 2.35 & 13.72 \\
\hline \multirow{2}{*}{ Available $\mathrm{P}, \mathrm{mg} \mathrm{kg}^{-1}$} & $0-30$ & 0.72 & 7.21 & 2.91 & 1.50 & 51.51 \\
\hline & $30-60$ & 0.98 & 4.70 & 2.41 & 1.17 & 48.60 \\
\hline \multirow{2}{*}{ Available $\mathrm{K}, \mathrm{mg} \mathrm{kg}^{-1}$} & $0-30$ & 19.07 & 251.09 & 79.89 & 48.88 & 61.19 \\
\hline & $30-60$ & 21.94 & 285.98 & 92.33 & 70.17 & 76.01 \\
\hline \multirow{2}{*}{ Available $\mathrm{Fe}, \mathrm{mg} \mathrm{kg}^{-1}$} & $0-30$ & 2.14 & 26.07 & 6.84 & 6.43 & 94.00 \\
\hline & $30-60$ & 1.78 & 21.72 & 5.71 & 5.37 & 93.99 \\
\hline \multirow{2}{*}{ Available $\mathrm{Mn}, \mathrm{mg} \mathrm{kg}^{-1}$} & $0-30$ & 0.58 & 13.55 & 3.65 & 2.95 & 80.94 \\
\hline & $30-60$ & 0.42 & 11.03 & 2.22 & 1.95 & 87.81 \\
\hline \multirow{2}{*}{ Available $\mathrm{Zn}, \mathrm{mg} \mathrm{kg}^{-1}$} & $0-30$ & 0.18 & 7.42 & 1.37 & 1.41 & 102.87 \\
\hline & $30-60$ & 0.16 & 6.68 & 1.27 & 1.27 & 100.57 \\
\hline \multirow{2}{*}{ Available $\mathrm{Cu}, \mathrm{mg} \mathrm{kg}^{-1}$} & $0-30$ & 0.01 & 3.06 & 0.37 & 0.52 & 141.75 \\
\hline & $30-60$ & 0.01 & 3.31 & 0.40 & 0.56 & 141.11 \\
\hline \multirow{2}{*}{ Available $\mathrm{B}, \mathrm{mg} \mathrm{kg}^{-1}$} & $0-30$ & 0.06 & 18.76 & 1.70 & 3.44 & 202.54 \\
\hline & $30-60$ & 0.06 & 17.70 & 2.79 & 5.14 & 184.35 \\
\hline
\end{tabular}

Assessment of soil data by principal component analysis

Principal component analysis was performed on soil datasets for only topsoil because topsoil and subsoil data exhibited very similar trend. Interpretation of the principal components (PCs) was aided by inspection of the factor-loading matrix extracted from a Varimax rotation with Kaiser normalization of main components to identify factors responsible for the grouping of the dataset. From scree plot graph of eigenvalues (Fig. 21), it shows that the first three components have eigenvalues more than one. Therefore, three components were extracted describing approximately $82.46 \%$ of the pattern variation (Table 2 ).

Egypt. J. Soil Sci. 56, No. 4 (2016) 


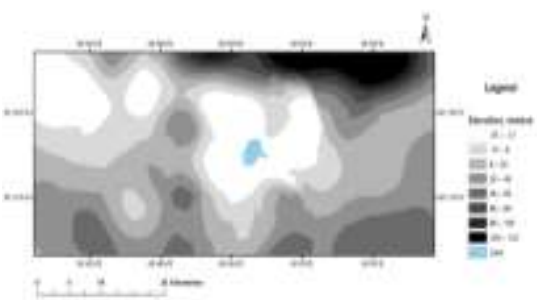

Fig. 2. Spatial distribution of elevation

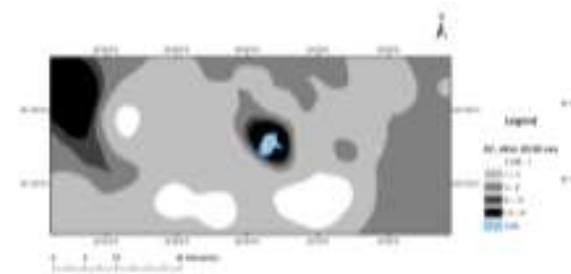

Fig. 4. Spatial distribution of subsoil EC

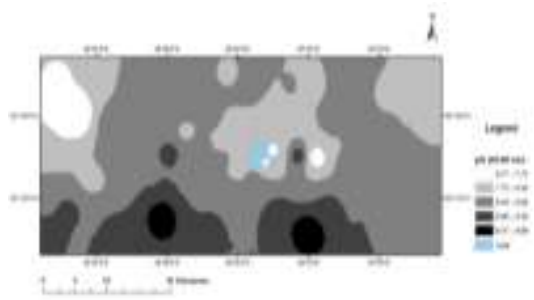

Fig. 6. Spatial distribution of subsoil $\mathrm{pH}$

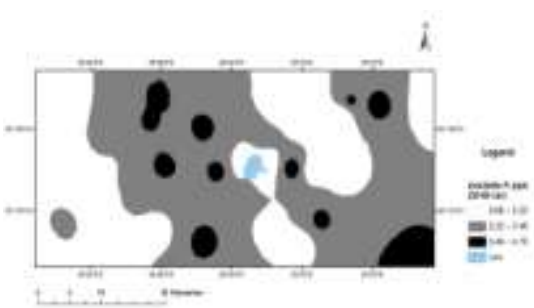

Fig. 8. Spatial distribution of subsoil available $P$

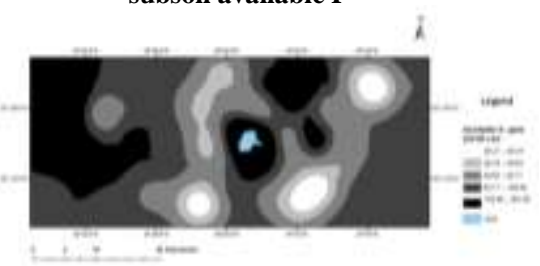

Fig. 10. Spatial distribution of subsoil available $\mathbf{K}$

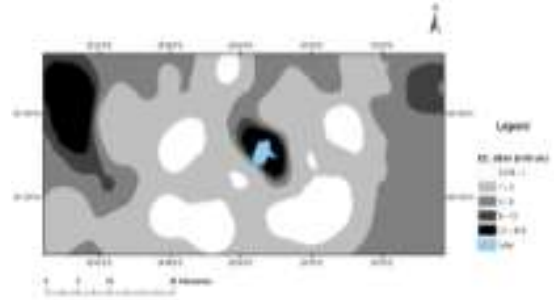

Fig. 3. Spatial distribution of topsoil EC

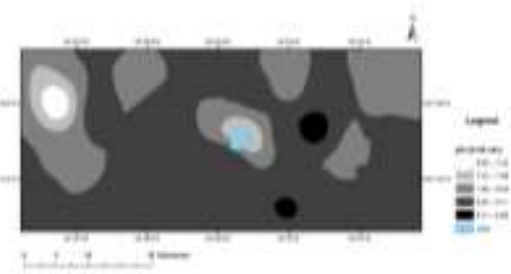

Fig. 5. Spatial distribution of topsoil pH

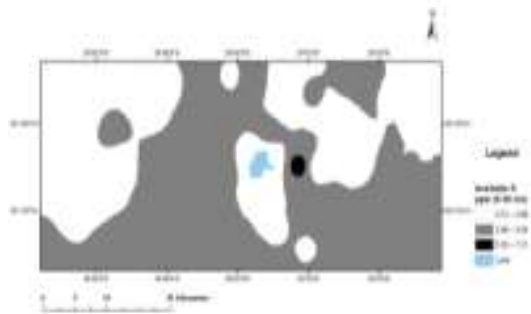

Fig. 7. Spatial distribution of topsoil available $\mathbf{P}$

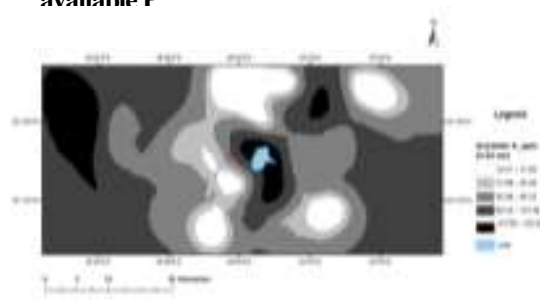

Fig. 9. Spatial distribution of topsoil available $K$

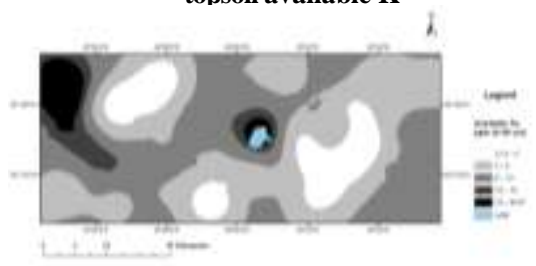

Fig. 11. Spatial distribution of topsoil available $\mathrm{Fe}$

Egypt. J. Soil Sci.56, No. 4 (2016) 


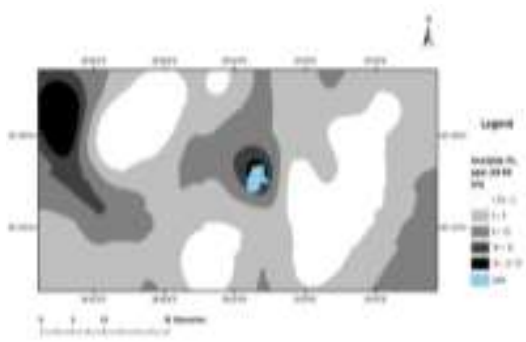

Fig. 12. Spatial distribution of subsoil available $\mathrm{Fe}$

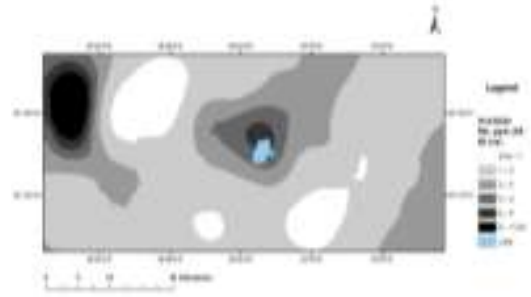

Fig. 14. Spatial distribution of subsoil available $M n$

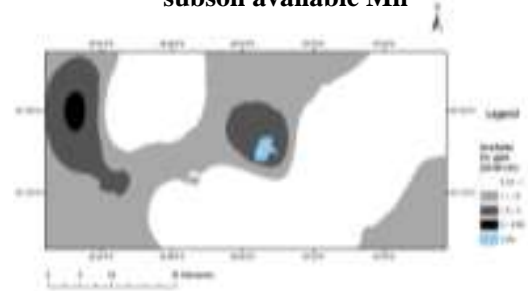

Fig. 16. Spatial distribution of suhsnil availahle $7 \mathbf{n}$

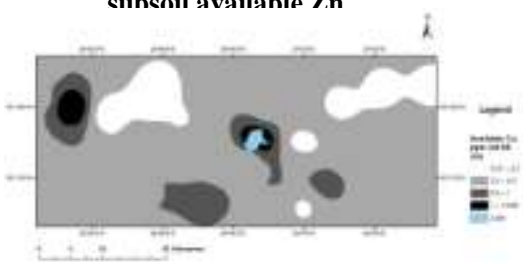

Fig. 18. Spatial distribution of subsoil available $\mathrm{Cu}$

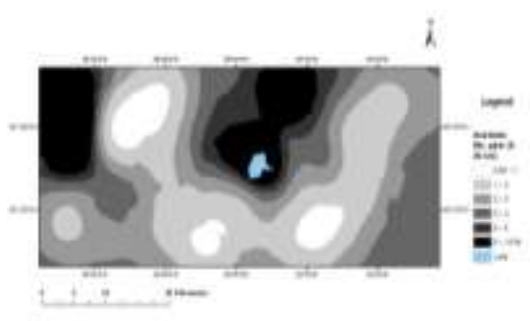

Fig. 13. Spatial distribution of topsoil available Mn

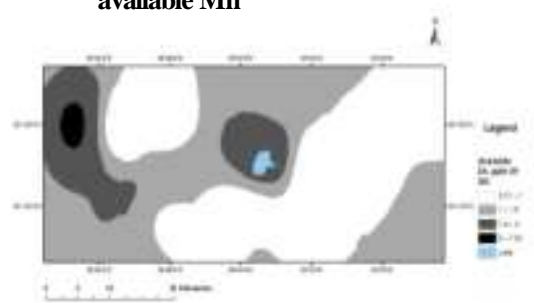

Fig. 15. Spatial distribution of topsoil available $\mathbf{Z n}$

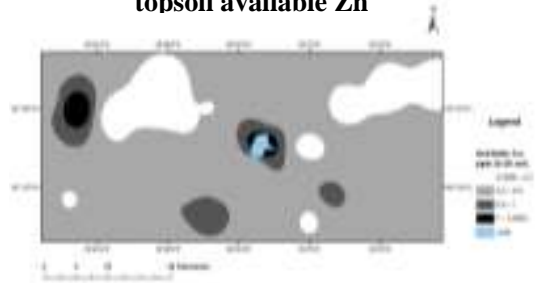

Fig. 17. Spatial distribution of topsoil available $\mathrm{Cu}$

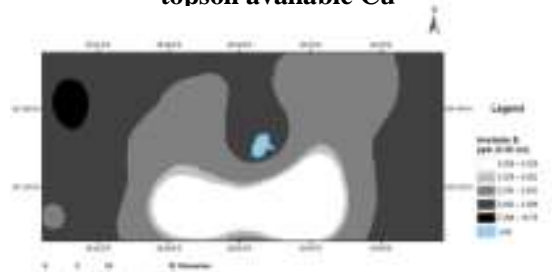

Fig. 19. Spatial distribution of i topsoil available B

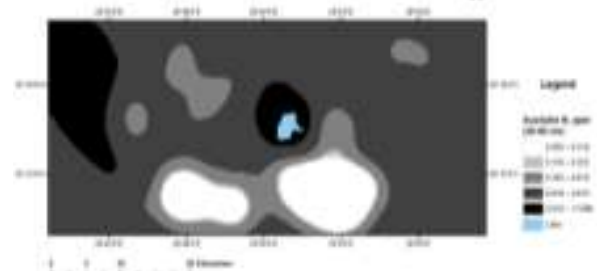

Fig. 20. Spatial distribution of subsoil available $B$

Egypt. J. Soil Sci. 56, No. 4 (2016) 


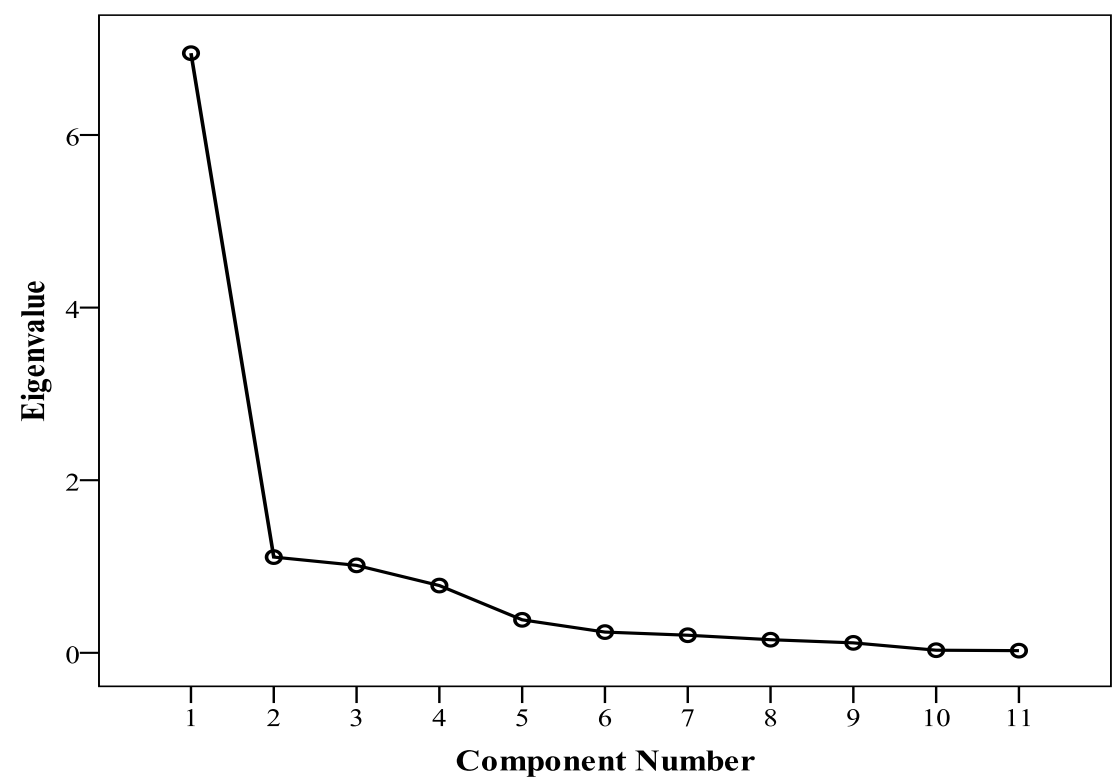

Fig. 21. The scree plot of eigenvalue against the component number of soil properties in Moghra Oasis area.

For the $\mathrm{PC} 1 ; \mathrm{EC}, \mathrm{pH}, \mathrm{K}, \mathrm{Fe}, \mathrm{Mn}, \mathrm{Zn}, \mathrm{Cu}$ and $\mathrm{B}$ define the structure and explain $56.15 \%$ of the variation (Table 2). There are positive relationships between EC and K, EC and Fe, EC and Mn, EC and Zn, EC and $\mathrm{Cu}, \mathrm{EC}$ and B. However, there were negative relationships between $\mathrm{pH}$ and $\mathrm{EC}, \mathrm{pH}$ and $\mathrm{K}, \mathrm{pH}$ and $\mathrm{Fe}, \mathrm{pH}$ and $\mathrm{Mn}, \mathrm{pH}$ and $\mathrm{Zn}, \mathrm{pH}$ and $\mathrm{Cu}, \mathrm{pH}$ and $\mathrm{B}$ (Table 2). For the PC2, only elevation defined the structure and explained $13.47 \%$ of the variation. However, $\mathrm{CaCO}_{3}$ defined the structure of the $\mathrm{PC} 3$ and explained $12.84 \%$ of the variation (Table 2).

Khan et al. (2014) analyzed magnetic data of Moghra Lake and concluded that the saline-water-bearing sandstone aquifer system is controlled by deep faults. Therefore, as the underground water rises, salts found naturally in rocks and soil are dissolved and move toward the soil surface. That could be the reason explaining high saline content at several parts of the area, especially at low elevations. Moreover, it appears that rocks types in this area are enriched in nutrients. That may justify the abundant and positive relation between soil salinity and available $\mathrm{K}, \mathrm{Fe}, \mathrm{Mn}, \mathrm{Zn}, \mathrm{Cu}$ and $\mathrm{B}$. However, the negative relationship between soil salinity and $\mathrm{pH}$ may be attributed to influence of neutral salts in decreasing soil $\mathrm{pH}$, as explained by Tan (2014). 
TABLE 2. Loadings between the first three principal component and soil parameters for soil properties extracted from Varimax with Kaiser normalization

\begin{tabular}{|l|c|c|c|}
\hline \multirow{2}{*}{} & \multicolumn{3}{|c|}{ Component } \\
\cline { 2 - 4 } & PC1 & PC2 & PC3 \\
\hline $\mathrm{EC}$ & -0.056 & 0.901 & -0.050 \\
\hline $\mathrm{pH}$ & $0.904^{*}$ & -0.238 & -0.191 \\
\hline $\mathrm{CaCO}_{3}$ & -0.802 & 0.175 & 0.430 \\
\hline $\mathrm{P}$ & -0.095 & -0.006 & 0.973 \\
\hline $\mathrm{K}$ & -0.444 & 0.445 & 0.254 \\
\hline $\mathrm{Fe}$ & 0.775 & -0.374 & -0.331 \\
\hline $\mathrm{Mn}$ & 0.794 & -0.410 & -0.080 \\
\hline $\mathrm{Zn}$ & 0.869 & -0.248 & 0.079 \\
\hline $\mathrm{Cu}$ & 0.963 & -0.018 & -0.078 \\
\hline $\mathrm{B}$ & 0.899 & 0.026 & -0.040 \\
\hline $\mathrm{Cumulative}$ variance, \% & 0.885 & -0.120 & -0.218 \\
\hline
\end{tabular}

"Values in boldface are the dominant in the eigenvector loadings by setting the level of significance at 0.7 .

The loadings plot of the three components in $3 \mathrm{D}$ dimensions is shown in Fig. 22. The plot reveals the relationship between variables in the space of the first three components. Three sub-clusters can be distinguished from the loadings. From the right, the first sub-cluster is composed of EC, K, Fe, Mn, Zn, $\mathrm{Cu}$ and $\mathrm{B}$. The second sub-cluster only formed by elevation. Finally, the third sub-cluster is composed of $\mathrm{pH}, \mathrm{CaCO}_{3}$ and $\mathrm{P}$. The clear separation between soil factors in the loadings plot indicates that these factors substantially interacted, both antagonistically and synergistically. In the first and third sub-clusters, EC and $\mathrm{pH}$ were selected as the correspondence parameters of the variations as these possessed more independent behavior than other factors. Based on these considerations, EC, elevation and $\mathrm{pH}$ could be selected to represent the variation in the whole dataset without affecting its quality. These parameters, then, function as direct and/or indirect indicators of the multiple soil parameters. Several studies (Verity \& Anderson 1990; Kravenchenko \& Bullock 2000 and Franzen et al., 2002) have used elevation and other soil data that satisfactorily explained the variation in grain yield at several places. 


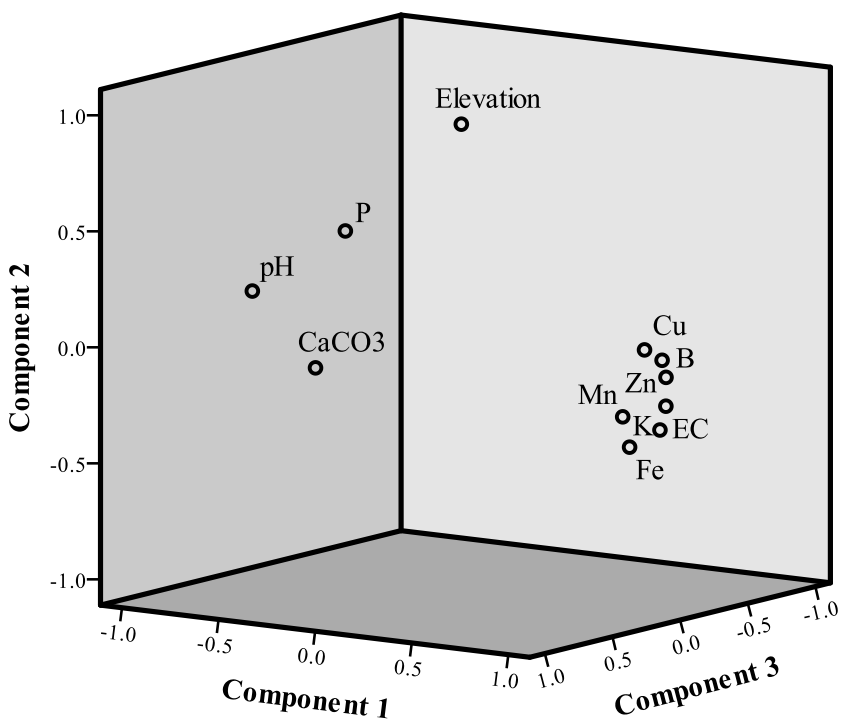

Fig. 22. Loadings plot of PC1, PC2 and PC3 for soil prosperities in Moghra Oasis area

\section{Delineating soil management zones}

Delineation of management zones is a way of classifying the overall spatial variability in an area according to the yield-limiting factors. The most meaningful parameters to include in the delineation technique must be those with most direct and/or indirect effect on soil fertility with high stability and obvious trend. Soil salinity, elevation and $\mathrm{pH}$ were selected previously as the parameters leading to the overall variation in the study area. Therefore, their layers have been overlaid to generate the management zones that accounts of the comprehensive evaluation of soil fertility.

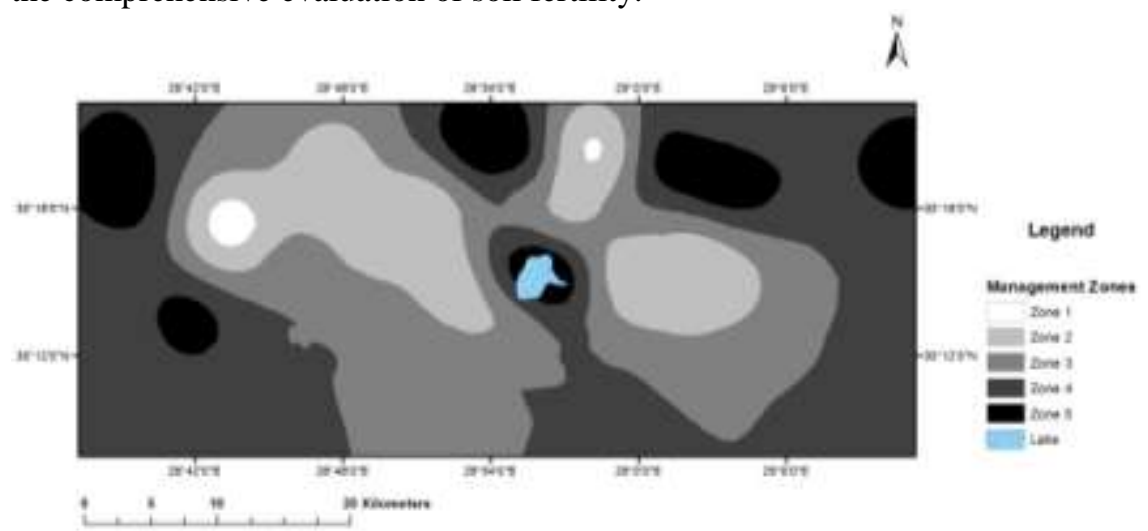

Fig. 23. Spatial distribution of the management zones in Moghra Oasis area

Egypt. J. Soil Sci. 56, No. 4 (2016) 
The overlay process generated a distinguished five zones as shown in Fig. 23. The zones priorities take the same direction of their numbers. Zones number one and two collectively were spread on an area of about 17000 ha. Whereas zone number three had an approximate area of 50000 ha. Zones number four and five constituted the rest areas. The delineation of management zones would be helpful for the decision makers to commence reclaiming the zones with fewer constraints. Furthermore, management zones approach is useful in optimizing the agricultural inputs, e.g. efficient use of fertilizers for maintaining high yield. Subsequently, the environment would be less at risk than when general recommendations are followed. This approach, therefore, has the potential to add to productivity and profit of the producers.

\section{Conclusions}

There existed considerable spatial variability in Moghra Oasis area. To create successful management zones, the most meaningful parameters to include in the delineation technique must be those reflecting the overall variation without affecting its quality. In view of that, PCA showed that soil salinity, elevation and $\mathrm{pH}$ are the parameters leading to the comprehensive variation in the study area. By overlaying these parameters altogether, five distinct zones have been generated. Using these zones as a complementary for variable application of agricultural inputs like fertilizers will reduce production costs as well as avoid the deterioration of environmental quality.

Acknowledgements: This work is part of a project on "Mapping Water and Soil Resources of Moghra Oasis" funded by the Desert Research Center, Egypt. We thank Prof. Dr. Ahmed Fawzy Yousef, the Principal Investigator of this project for his valuable suggestions and support.

\section{References}

Ali, A.M., Soliman, K.G., Atiat, E., and Kamh, R.N., (2008) Evaluation of soil fertility status at West Delta area using GIS technique. Zagazig J. Agric. Res., 35, 1053-1142.

Bruulsema, T.W., Malzer, G.L., Robert, P.C., Davis, J. G. and Copeland, P.J., (1996) Spatial relationships of soil nitrogen with corn yield response to applied nitrogen. In P. C. Roberts, R.H. Rust and W. E. Larson (Eds.), Proceedings of Third International Conference on Precision Agriculture (pp. 505-512). Minneapolis, MN, 23-26 June 1996. Madison, WI: ASA, CSSA, SSA.

Burrough, P.A. and McDonnell R.A., (1998) Principles of Geographical Information Systems. Oxford University Press, New York.

Cassel, D.K., Kamprath, E.J. and Simmons, F.W., (1996) Nitrogen-sulfur relationships in corn as affected by landscape attributes and tillage. Agronomy Journal, 88:133-140.

Csomos, E., Heberger, K. and Simon-Sar-kadi, L., (2002) principal component analysis of biogenic amines and polyphenols in Hungarian wines. Journal of Agricultural and Food Chemistry, 50, 3768-3774.

Egypt. J. Soil Sci. 56, No. 4 (2016) 
Dahnke, W.C. and Johnson, G.V., (1990) Testing soils for available nitrogen, in R.L. Westerman, Ed., Soils Testing and Plant Analysis, $3^{\text {rd }}$ ed., SSSA Book Series, Number 3, Soil Science Society of America, Madison, W I, USA.

Da-Silva Tores E.A.F., Garbelotti M.L., Neto J.M.M., (2006) The application of hierarchical cluster analysis to the study of the composition of foods. Food Chem. 99, 622-629.

Doerge, T., (1999) Defining management zones for precision farming. Crop Insights, 8 (21), 1-5.

FAO, (1988) Salt-affected Soils and Their Management. FAO Soils Bull. 39. FAO, Rome, Italy. $131 \mathrm{pp}$.

Filip, Z., (2002) International approach to assessing soil quality by ecological related biological parameters. Agriculture, Ecosystems and Environment, 88 (2), 169-174.

Fraisse, C.W., Sudduth, K.A. and Kitchen, N.R., (2001) Delineation of site-specific management zones by unsupervised classification of topographic attributes and soil electrical conductivity. Trans. ASAE 44 (1), 155-166.

Franzen, D.W., Hopkins, D.H., Sweeney, M.D., Ulmer, M.K. and Halvorson, A.D., (2002) Evaluation of soil survey scale for zone development of site-specific nitrogen management. Agron. J. 94, 381-389.

Garey, A.F. and Roopa, M., (2005) Soil property analysis using principal components analysis, soil line and regression models. Soil Sci. Soci. Amer. J., 69 (6), 1782-1788.

Gaston, L.A., Locke, M.A., Zablotowicz, R.M. and Reddy, K.N., (2001) Spatial variability of soil properties and weed populations in the Mississippi delat. Soil Sci. Soc. Am. J., 65, 449-459.

Hammer O., Harper D.A.T. and Ryan P.D., (2001) Past: Paleontological Statistics Software Package for Education and Data Analysis. Palaeontol Electron, 4 (1), 9

Hung, Y. and Yang, Z., (2009) Recent research progress of overseas soil quality evaluation. Geological Bulletin of China, 28 (1), 130-136.

Inman, D., Khosla, R., Westfall, D.G. and Reich, R., (2005) Nitrogen uptake across site specific management zones in irrigated corn production systems. Agron. J. 97 169-176.

Khan, S.D., Fathy, M.S., Abdelazeem, M., (2014) Remote sensing and geophysical investigations of Moghra Lake in the Qattara Depression, Western Desert, Egypt. Geomorphology, 207, 10-22.

Khosla, R. and Shaver T., (2001) Zoning in on nitrogen needs. Colorado State Univ. Agron. Newsletter, 21 (1), 24-26.

Koch, B., Khosla, R., Frasier, W.M., Westfall, D.G. and Inman, D., (2004) Economic feasibility of variable-rate nitrogen application utilizing site-specific management zones. Agron. J. 96, 1572-1580. 
Kravenchenko, A.N. and Bullock, D.G., (2000) Correlation of corn and soybean grain yield with topography and soil properties. Agron. J., 92, 75-83.

Lambert, D.M., Lowenberg-DeBoer, J. and Malzer, G.L., (2006) Economic analysis of spatialtemporal patterns in corn and soybean response to nitrogen and phosphorus. Agron. J. 98, 43-54.

Li, M. and Zhang, X., (2011) GIS-based evaluation of farm land soil fertility and its relationships with soil profile configuration pattern. Chinese J. of Applied Ecology, 22(1), 129-136.

Mulla, D.J. and Schepers J.S., (1997) Key processes and properties for site-specific soil and crop management. p. 1-18. In E.J. Sadler (Ed.) The State of Site-specific Management for Agriculture. ASA, CSSA, and SSSA, Madison, WI.

Page, A.L., Miller, R.H. and Keeney, D.R., (1982) Methods of Soil Analysis, Part 2, Chemical and Microbiological Properties, $2^{\text {nd }}$ ed., Agronomy Series No 9, American Society of Agronomy, Madison, WI.

Scharf, P.C., Kitchen, N.R., Sudduth, K.A., Davis, J.G., Hubbard, V.C. and Lory, J.A., (2005) Field scale variability in optimal nitrogen fertilizer rate for corn. Agron. J. 97, 452-461.

Schepers, J.S., Schlemmer, M.R. and Fergunson, R.B., (2000) Site-specific considerations for managing phosphorus. J. Environ. Qual. 29,125-130.

Soltanpur, P.N., (1991) Determination of nutrient element availability and elemental toxicity by the AB-DTPA soil test and ICPS. Adv. Soil Sci. 16,165-190.

Tan, K.H., (2014) Principles of Soil Chemistry, Fourth edition. CRC Press, Taylor and Francis Group p. 362.

Varma, A., (1991) Handbook of Inductively Coupled Plasma Atomic Emission Spectroscopy. Boca Raton, FL: CRC, Inc.

Verity, G.E., and Anderson, D.W., (1990) Soil erosion effects on soil quality and yield. Canadian J. Soil Sci., 70, 471-484.

Wilding, L.P., Bouma, J., and Goss, D.W., (1994) Impact of spatial variability on interpretive modeling. In: Quantitative Modeling of Soil Forming Processes, edited by R.B. Bryant and R.W. Arnold. SSSA special publication No. 39, Madison, WI, USA, pp. 61-76.

Wu, Y., Tian, X., Tong, Y., (2010) Assessment of integrated soil fertility index based on principal component analysis. Chinese J. of Ecology, 29 (1), 173-180.

Zheng, L., Yu, W., Ma, Q., (2004) Advances in the integrated evaluation of farmland fertility. Chinese J. of Ecology, 23 (5), 156-161. 
EVALUATION OF SOIL FERTILITY USING MULTIVARIATE ANALYSIS... 603

تقييم خصوبة التربة باستخدام التحليل متعدد المتفيرات ونظم المطلومات

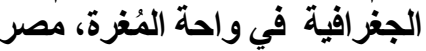

علي محمد محم علي و شريف محمود ابراهيم

قسم خصوبة وميكروبيولويف الأرواضي ابراهيم - مركز بحوث الصحر اء - القاهرة - مصر

إن فهم التغيرات المكانية لخصائص التربة هام لتحسين إدارة خصوبة التربة

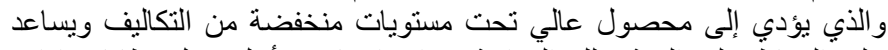

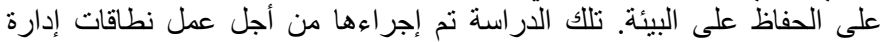

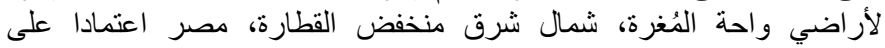

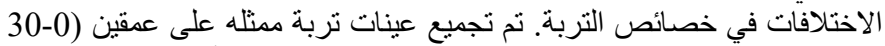

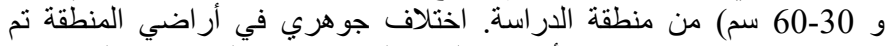

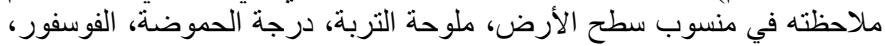

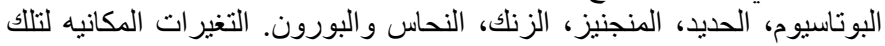

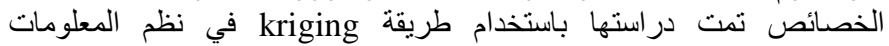

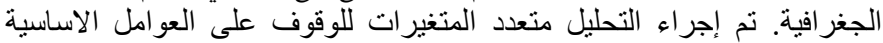

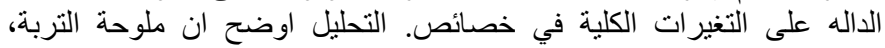

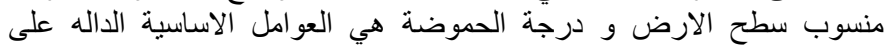

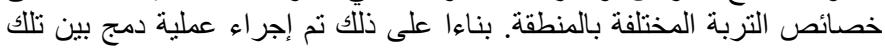

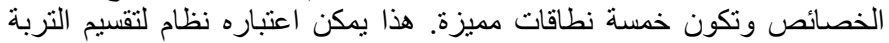

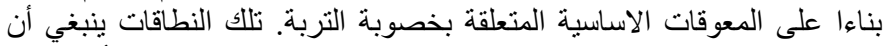

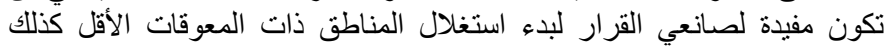

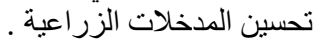

